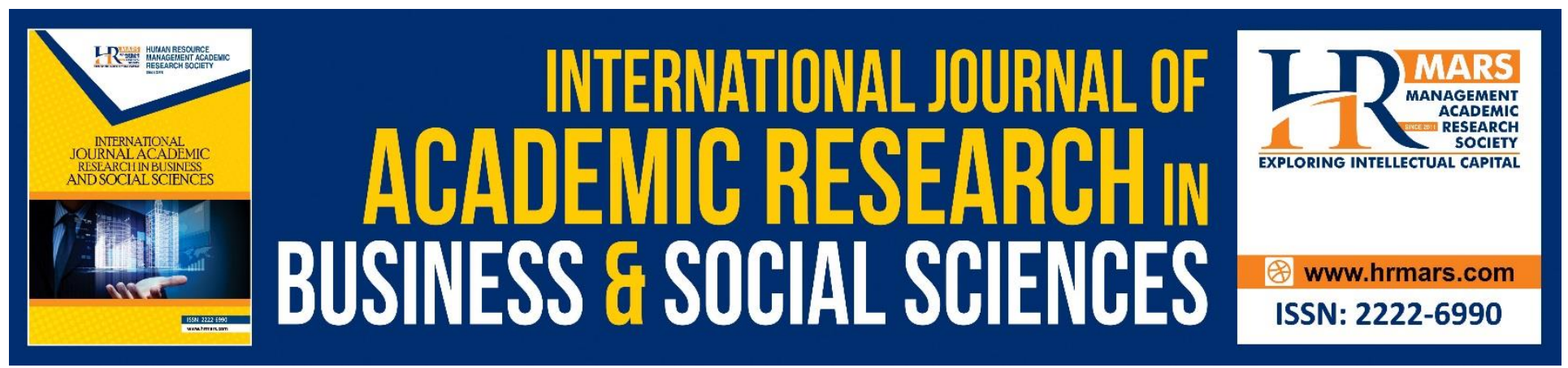

\title{
Differences in Levels of Control Object Skills among Grade 1 Ballet Dancers, Students with Co-Curricular and Students without Co-Curricular
}

Borhannudin Abdullah, Hanis Mohd Khalid, Nur Anati Lokman, Muhammad Noor Hizami Hamidi

To Link this Article: http://dx.doi.org/10.6007/IJARBSS/v8-i12/5047

DOI: $10.6007 /$ IJARBSS/v8-i12/5047

Received: 18 Nov 2018, Revised: 17 Dec 2018, Accepted: 25 Dec 2018

Published Online: 28 Dec 2018

In-Text Citation: (Abdullah, Khalid, Lokman, \& Hamidi, 2018)

To Cite this Article: Abdullah, B., Khalid, H. M., Lokman, N. A., \& Hamidi, M. N. H. (2018). Differences in Levels of Control Object Skills among Grade 1 Ballet Dancers, Students with Co-Curricular and Students without CoCurricular. International Journal of Academic Research in Business and Social Sciences, 8(12), 491-498.

\section{Copyright: (c) 2018 The Author(s)}

Published by Human Resource Management Academic Research Society (www.hrmars.com)

This article is published under the Creative Commons Attribution (CC BY 4.0) license. Anyone may reproduce, distribute, translate and create derivative works of this article (for both commercial and non-commercial purposes), subject to full attribution to the original publication and authors. The full terms of this license may be seen

at: http://creativecommons.org/licences/by/4.0/legalcode

Vol. 8, No. 12, 2018, Pg. 491 - 498

Full Terms \& Conditions of access and use can be found at http://hrmars.com/index.php/pages/detail/publication-ethics 


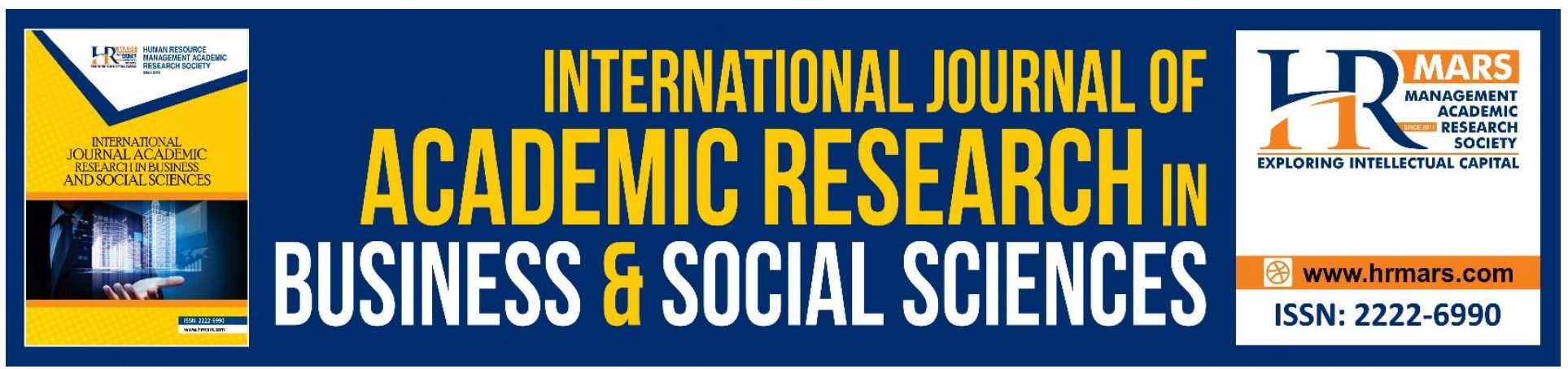

\title{
Differences in Levels of Control Object Skills among Grade 1 Ballet Dancers, Students with Co-Curricular and Students without Co-Curricular
}

\author{
Borhannudin Abdullah, Hanis Mohd Khalid, Nur Anati Lokman, \\ Muhammad Noor Hizami Hamidi \\ Faculty of Educational Studies, Universiti Putra Malaysia, 43400 UPM Serdang, Selangor Darul \\ Ehsan, Malaysia
}

\begin{abstract}
Purpose: The purpose of this study was to identify the differences between level of control of object skills of grade one ballet dancers, students who were actively involved in co-curricular activity and students who were not actively involved in co-curricular activity. Methods: A study was conducted in the form of ex-post facto studies involving a total of 90 students, male and female who lived in Klang and Seremban districts. Test of Gross Motor Development (TGMD-2) was carried out to determine the skill level of the student based on the six control object skills that has been determined. Data were obtained through video footage and raw skill transcript score by reference norm age equivalents control objects. Kruskal-wallis statistical analysis was used to analyze the differences in level of control object skill group study. Findings: The findings of this study shows that the group of students who were actively involved in co-curricular activities has the highest mean $(M=3.07, S D=$ 1.14 ) in the control object skills as compared to a group of students who were not actively involved in co-curricular activities $(M=2.73, S D=0.98)$ and grade one ballet dancers $(M=2.00, S D=0.00)$. Meanwhile, it was found that there are significant differences between the three groups of study with estimated significant of 0.00. Discussions: Study shows the progress of the student control object skills grade one ballet dancers, students who were actively involved in co-curricular and student without co-curricular involvement are inactive according to their chronological age Keywords: Control Object Skills, Co-Curriculum, Ballet Dancers, Motor Development
\end{abstract}

\section{Introduction}

Children's object control skills refer to the level of physical co-ordination skills and children's motors to allow these two elements to while children move certain objects using their physical members in the right way (Khairi, 2016).Control Object skills children refers to the level of physical and motor skills coordination of children to enable both elements to interact while children push certain objects 
using physical manner in the correct way (Khairi, 2016). Pass studies shows that children who have problems in the development of these skills will experience communication problems, socializing issues with friends, less participating in team games, less ambitious and future goals when they become an adult. It is extremely important to know the information about the level of development of existing object control skills of children to be used as a guideline for monitoring the growth and development of the children. In this case, the assessment of object control skills development is important to identify children who have problems in the process of development or as expected. Generally, early inspection or assessment skills control object is necessary to identify the nature and extent of the needs of children, in determining if additional diagnostic testing is needed. Inspection is also necessary in determining the appropriate type of enrichment for promoting optimal development, and in the projected development of neuro potential at the age of late (Khairi, 2016). In an atmosphere of school readiness, object control skills are very important to plan and develop appropriate teaching strategies so that the appropriate experience for children can be implemented. It is also important to provide relevant information to the assessment of a child's object control skills to parents and other concerned individuals, especially to those who are willing to or those who can participate in providing adequate support to children with special needs.

According to Ulrich (2015), one way to assess the level of motor development of children is through their object control skills. This is because according to Ahmad and Masri (2014), the development of child's object control skills influences the development of their locomotor skills because the needs of the knowledge and experience to perform object control skills is higher as compared to the knowledge and experience needed to perform locomotor skills. This statement is supported by other studies carried out by-Borhannudin (2011), where the findings of studies conducted by the researcher shows delay age equivalents score for object control skills which was higher than the locomotor skills. In addition, the factors that led to the lower rate of children's object controlling skills development as compared to their locomotor development is because object control skills require more specific training than locomotor skills (Westendrop, Hartman, Houwen, Smith \& Visscher, 2011).

Findings from previous study also shows that the development of student's object control skill at a primary school level in Malaysia is not according to their chronological age (Masri, Ahmad, mahaliza, 2014). This Policy indicates the upbringing and education of early childhood National 2008 (PERMATA, 2008) has failed to achieve. Among the objectives contained in the policy is to provide quality education and care for young children to stimulate their initial growth by age group in terms of physical, cognitive, language, socio-emotional and spiritual a safe, healthy and enjoyable.

Referring to the PERMATA Malaysia program (2008), the development of motor skills in children should be done at the early stage of their age because the potential learning started in early childhood or even before they were born to the world. At this point, early learning and teaching should be initiated to help them achieve comprehensive developments in terms of spiritual and physical. This happens due to a teacher who has a lack of knowledge about the development of the skills the student object control in primary schools (Masri, Ahmad, \& Mahaliza, 2014). Furthermore, the issue of the implementation of the physical education class is always considered a subject that is 
not important in students ' learning in Malaysia. This is because parents and the school are focusing only on academic achievement (Wee, 2013). As a result, the primary school students failed to master their object controlling skills at the proper age.

On the other hand, previous study also stated that primary school students had less exposure against the use of object control skills when carrying out physical activity in primary schools (Lopes, Santos, Pereira and Lopes, 2013). This happens because the teachers have minimal exposure to the use of norms or instrumentations to measure the extent of the object control skills (Masri, Ahmad, \& Mahaliza, 2014). Many studies on the object control skill development level has been done before but still there is no study comparing levels of development skills control objects between grade one Ballet students, children involved in the co-curricular activities and children who did not involve in co-curricular activities. The purpose of this study was to identify the level of skill development of grade 1 ballet dancers' object controls, the student involved in the co-curricular activities and students who did not engage with co-curricular in year 1 primary school.

\section{Methods of Study}

This study was conducted in the form of ex-post facto. This method was chosen because the characteristics of the subject involved were naturally occurring as well as researchers did not make any manipulations on these features. This study comprises a total of 90 children male and female around the District of Klang and Seremban and each group consists of 30 people as the subject.

\section{Instrumentations}

Subjects were tested using a scale TGMD-2 (Ulrich, 2015), consisting of 12 basic gross motor skills development i.e. 6 locomotor skills and 6 object control skills. For this study, out of 12 basic skills, only 6 skills of control objects were used to determine the criteria of the study (striking a stationary ball, dribble stationary, catch, kick, throw overhand, underhand roll). Among the tools used to test the proficiency of object control skills are: a set of computers, one video recorder, Kinovea application equipped Lenovo brand, cones, Ribbon sticker, 4.5 "bean bags, plastic sticks, soccer balls, softball, beating tee, 4 " plastic balls, and a tennis ball.

\section{Data Collection}

Researchers used Nikon D3600 DSLR cameras to record the video and to analyse the final score for the test run. Two trials were given to each subject for each skill and the yut were evaluated according to the criteria explained in scale TGMD - 2. To all 6 control object skills that have already burned transferred into the laptop Lenovo equipped applications Kinovea. The raw score for object control skills for each subject given by observation the slow motion using Kinovea subject their natural behavior. Giving a score of 1 is for subjects that meet the criteria for testing and a score of 0 is given if the subject does not meet the criteria of the tests carried out.

\section{Results of the Study}

Object control skills scores were descriptively analysed to assess the mean, standard deviation, minimum and maximum (refer table 1). 
INTERNATIONAL JOURNAL OF ACADEMIC RESEARCH IN BUSINESS AND SOCIAL SCIENCES

Vol. 8, No. 12, Dec, 2018, E-ISSN: 2222-6990 C 2018 HRMARS

Table 1: Object Control Skills Scores by Group of Students

\begin{tabular}{|c|c|c|c|c|c|}
\hline & $\mathrm{N}$ & & Maximum & Min & Standard deviation \\
\hline \multicolumn{6}{|c|}{ Minimum } \\
\hline Student ballet Grade 1 & 30 & 2.00 & 2.00 & 2.00 & .00 \\
\hline students with co curriculum & 30 & 2.00 & 6.00 & 3.07 & 1.14 \\
\hline $\begin{array}{l}\text { students without co- } \\
\text { curriculum }\end{array}$ & 30 & 2.00 & 4.00 & 2.73 & .98 \\
\hline
\end{tabular}

The mean differences between the three groups of subjects were analysed using non-parametric analysis methods, namely, Kruskal-Wallis because data distribution is not normal. Test results showed students with co-curricular involvement has the highest mean score (55.18), followed by students without co-curricular involvement (48.82) and grade 1 ballet students shows the lowest mean score (32.50) (refer table 2). Significant test results done shows that there are significant differences between these three groups with an estimated value of 0.000 significant(refer table 3 ).

Table 2: Mean Differences between Groups

\begin{tabular}{|c|c|c|c|}
\hline & Subject & $\mathrm{N}$ & Mean Rank \\
\hline \multirow[t]{4}{*}{ Object control score } & Grade 1 ballet students & 30 & 32.50 \\
\hline & $\begin{array}{l}\text { Students with } \\
\text { involvement }\end{array}$ & co-curricular $_{30}$ & 55.18 \\
\hline & $\begin{array}{l}\text { Students without } \\
\text { involvement }\end{array}$ & co-curricular 30 & 48.82 \\
\hline & Total & 90 & \\
\hline
\end{tabular}

Table 3: Significant Differences Value between Groups

$$
\text { Object control skills }
$$

\begin{tabular}{cl}
\hline Chi-Square & 19.439 \\
$\mathrm{df}$ & 2 \\
Asymp. Sig. & .000 \\
a. Kruskal Wallis Test & \\
\hline
\end{tabular}




\section{Discussions}

Descriptive analysis findings (table 1) showed a children's performance for all three groups, namely the Group of students who attended co-curricular activities $(M=3.07, S D=1.14)$, group of students without co-curriculum $(M=2.73, S D=0.98)$ and group dancers Ballet $(M=2.00, S D=0.00)$. For test results of Kruskal-Wallis (table 2) an group of students with curriculum has a mean rank the highest (55.18) while students without co-curricular has the second highest mean score (48.82) and children who participate in ballet dance has the lowest mean score (32.50).

The findings show that students who were involved in co-curricular activities is a student who is active in the development of the skills of object control skills than students without co-curricular activity involvement and grade 1 ballet dancer. This is supported by previous research stating that by practicing skills, encouragement and instructions provided, children can develop their motor skills (Burchinal, Campbell, Bryant, Wasik, \& Ramey, 1997; Cleland \& Gallahue, 1993). Ballet dance routine training may be able to build large muscle strength to facilitate the movement of students but due to locomotor physical activity limited to one type of physical activity only, this causes the object control skills students to not grow in line with their chronological age. In addition, there are studies reported that the development of motor skills of preschool children is positive and there is contact with their participation in activities (Fisher, Reilly, Kelly, Montgomery, Williamson, Paton \& Grant, 2005).

This is because, students who were actively involved in co-curricular activities are exposed and always got through a process of development of this motor in a natural way. Not only that, most co-curricular activities in school is somehow extreme in nature when compared to the ballet dancing which is more passive in nature. In addition, students involved in co-curricular activities are always playing with the equipment available. They are involved in a variety of sports activities involving the use of tools, such as hitting the shuttle cock with racket, kick the ball, throwing the ball as well as celebrate the ball. All object skill requires control of balance and a more systematic coordination between the organs of the senses and touch to repair gross and fine motor student. In addition, past research from researchers Haywood and Getchell (2009) also explains the gross motor development as a change in the ability of the nervous system in controlling muscles motor skills throughout life as a result of the interaction between tasks, individuals and the environment. In the gross motor movements and behaviour, children need guidance and continuous training so that they can maintain the associated movement. According to Ahmad Hashim (2004), the main objectives of the physical education subject is to provide opportunities for all school children so that they have competency in gross motor skills, particularly skills control objects.

\section{Conclusion}

Development level of object control skills among primary school students remained in the level of concern especially for students who have physical activity limited to one type of physical activity only just like the grade 1 ballet students. Development of object control skill is not growing in line with the equivalents age and they should have been ready to step into one another level. Generally, these findings needs to be considered by the parties involved in the development of motor skills of children, such as teachers and parents especially in children at an early age. All motor skills need to be disclosed 
INTERNATIONAL JOURNAL OF ACADEMIC RESEARCH IN BUSINESS AND SOCIAL SCIENCES

Vol. 8, No. 12, Dec, 2018, E-ISSN: 2222-6990 C 2018 HRMARS

in advance so that the children are more willing to step up and interact in life with more confidence and enthusiasm.

\section{Suggestions}

The performance of the three groups shows that there are differences in the skill level of object control in children the level of an elementary school. Researchers suggest the assessment and measurement of the object control skills to be specifically done and practiced in the early stage of schooling by educators to monitor and improve motor development of children. Assessment and measurement must also be done from time to time to put these children at a level the development of motor skills in line with their chronological age. Educators can also help repair their motor skills gradually and be able to help children to master the gross motor skills along with their chronological age.

\section{References}

Ahmad, H., (2004). Measurement of Motor Fitness. Tanjong Malim, Perak; Quantum Books

Ahmad, H. \& Masri, B., (2014). Research level of gross motor development and age equivalents of children 7 to 9 years. International Journal of Education Learning and Development. Vol.2, No.4, pp.48-59

Division of Early Childhood Education (PERMATA). (2008). Curriculum Jewel country: Parenting and early childhood education 0-4 years. Prime Minister Malaysia.

http://www.jpnin.gov.my/documents/10124/949313/KURIKULUM PERMATA NEGARA .PDF

Borhannudin, A., (2011). The impression of a traditional game into the top of a rugged motor development stage in childhood among the ranks of early schooling.

http//: www. educ. upm on 28 January 2016

Burchinal, M. R., Campbell, F. A., Bryant, D. M., Wasik, B. H., \& Ramey, C. T. (1997). Early intervention and mediating process in cognitive performance of children of low-income African American families. Child development, 5, 935-954

Fisher, A., Reilly, J.J., Kelly, L.A., Montgomery, C., Williamson, A., Paton, J., \& Grant, S. (2005). Fundamental movement skills and habitual activity in young children. Medicine Science in Sports and Exercise, 37, 4, 684-688

Haywood, K.M. \& Getchell, N. (2009). "Life Span Motor Development" (5 $5^{\text {th }}$ ed). Champaign: Human Kinetic

Masri, B., Ahmad. H., \& Mahaliza. M. (2014). Gross motor development level of the children age 9 years: A case study. International Journal for Innovation Education and Research, 2(11), 129135

Khairi, Z. (2016). Valuation of motor development stage rough early childhood schooling. Retrieved from www.Academia.edu On 17 March 2016

Lopes, L., Santos, R., Pereira, B \& Lopes, P. V. (2013). Associations between gross Motor Coordination and Academic Achievement in elementary school children: Journal of Human Movement Science. (32) 9-20. doi:10.1016/j.humov.2012.05.005

Ulrich, A. D. (2015). Test of Gross Motor Development - 2 (TGMD2). ProEd, Inc 
INTERNATIONAL JOURNAL OF ACADEMIC RESEARCH IN BUSINESS AND SOCIAL SCIENCES

Vol. 8, No. 12, Dec, 2018, E-ISSN: 2222-6990 @ 2018 HRMARS

Westerndrop, M., Hartman, E., Houwen, S., Smith, J \& Visscher, C. (2011). The relationship between gross motor skills and academic achievement in children with learning disabilities. 2773-2779. doi:10.1016/j.ridd.2011.05.032

Wee, E. (2013). Contemporary Issues in the Teaching of PE in Malaysia. Journal of sport activity. http://jpaspex.com/index.php/JPASE/article/view/19 